\title{
IMPLEMENTASI TEKNOLOGI SILASE RUMPUT GAJAH MINI MENUJU DESA MANDIRI PAKAN TERNAK
}

\author{
Bela Putra ${ }^{1}$ dan Budi Prastia ${ }^{2}$ \\ ${ }^{1}$ Prodi Peternakan Universitas Muara Bungo \\ ${ }^{2}$ Prodi Agroteknologi Universitas Muara Bungo \\ belaputramsc@gmail.com \\ prasetiabudi_umb@yahoo.com
}

\begin{abstract}
Abstrak
Kendala budidaya sapi potong pada kelompok Tani Purwodadi 2 adalah keterbatasan hijauan pada musim kemarau sehingga menyebabkan menurunnya produktivitas ternak. Salah satu upaya untuk meningkatkan produktivitas ternak adalah dengan menyediakan hijauan pakan dalam kuantitas dan kualitas yang cukup sepanjang tahun. Pemanfaatan rumput gajah mini sangat cocok diaplikasikan teknologi tepat guna berupa teknologi silase dengan tujuan untuk menambah daya tahan simpan, meningkatkan palatabilitas, serta meningkatkan kecernaan pada sapi potong. Tujuan dari pengabdian ini adalah untuk mengaplikasikan teknologi pengawetan hijauan pada kelompok Tani Purwodadi 2 Kuamang Kuning Kabupaten Bungo. Metode pelaksanaan pengabdian ini adalah memberikan penyuluhan serta prkatik aplikasi teknologi pembuatan silase. Kegiatan penyuluhan berupa memberikan pemahaman kepada kelompok tani tentang budiddaya rumput gajah mini, keunggulan serta urgensi pengawetan hijauan. Pelaksanaan praktik aplikasi teknologi silase dengan menggunakan mesin pencacah dan bahan-bahan berbasis sumber daya lokal. Hasil pengabdian ini menunjukkan adanya perubahan paradigma kelompok tani Purwodadi 2 untuk meningkatkan produktivitas hijauan pada musim hujan dan mengaplikasikan teknologi silase, serta kelompok tani Purwodai 2 mampu memproduksi silase berbasis hijauan secara mandiri.
\end{abstract}

Kata Kunci: rumput gajah mini, silase, hijauan

\section{PENDAHULUAN}

Kendala budidaya sapi potong pada kelompok Tani Purwodadi 2 adalah keterbatasan hijauan pada musim kemarau sehingga menyebabkan menurunnya produktivitas ternak. Riswandi (2014) menyatkan bahwa kondisi yang tidak seimbang antara populasi ternak dengan ketersediaan hijauan adalah faktor utama yang menjadi kendala dalam usaha peternakan. Salah satu upaya untuk meningkatkan produktivitas ternak adalah dengan menyediakan hijauan pakan dalam kuantitas dan kualitas yang cukup sepanjang tahun.

Pemanfaatan rumput gajah mini untuk sumber pakan hijauan ternak sapi sangat potensial untuk dikembangkan. Rumput gajah mini
(Pennisetum purpureum CV. Mott) adalah salah satu jenis rumput unggul dengan kandung gizi yang tinggi dan sangat disukai ternak. Budidaya rumput gajah mini dikategorikan mudah untuk dikembangkan dengan ciri-ciri mudah tumbuh, pertambahan rumpun cepat serta mudah beradaptasi dengan lingkungan (Putra, 2020) Akhir-akhir ini banyak penelitian seputar pengembangan dan pemanfaatan rumput gajah mini pada usaha peternakan.

Upaya untuk mempertahankan ketersediaan rumput gajah mini pada musim kering adalah dengan penerapan teknologi silase. Aplikasi teknologi tepat guna berupa teknologi silase dengan tujuan untuk menambah daya tahan simpan, meningkatkan palatabilitas, serta meningkatkan 
kecernaan pada sapi potong. Thalib (2016) menyatakan bahwa rumput gajah mini adalah jenis rumput unggul dengan produktivitas tinggi dan disukai oleh ternak dan sangat cocok untuk dijadikan silase.

Silase adalah proses pengawetan bahan hasil samping produk pertanian dengan hasil berupa produk fermentasi (Astutui, dkk, 2019). Teknologi silase dengan menggunakan EM4 dan penambahan zat aditif dapat meningkatkan kualitas silase. Sesuai dengan hasil penelitian (Berampu, dkk 2020) menunjukkan bahwa EM4 dan zat aditif dapat meningkatkan kualitas silase pada rumput gajah mini. Berbagai macam bahan aditif yang bisa dijadikan pada teknologi silase adalah biji-bijian, molasses, dedak halus dan produk sampingan industry pertanian (Yitbarek dan Tamir, 2014). Pemanfaatan zat aditif berbasis sumber daya lokal juga menentukan keberlanjutan aplikasi silase. Salah satu sumber daya local yang bisa digunakan sebagai zat aditif adalah Indigofera sp. Akhir-akhir ini sangat banyak pemanfaatan indigofera $s p$ di lingkungan peternakan (Putra, $d k k$ 2020).

Tujuan dari pengabdian kepada masyarakat ini adalah untuk mengaplikasikan teknologi pengawetan hijauan pada kelompok Tani Purwodadi 2 Kuamang Kuning Kabupaten Bungo dangan harapan terciptanya kemandirian pakan ternak.

\section{METODE}

\section{Waktu dan tempat}

Kegiatan PKM dilaksanakan pada bulan Juni - Juli tahun 2020 di Dusun Tirta Mulya. Jl. Serindit RT 12/03. Kec. Pelepat Ilir, Kab. Bungo. Lokasi Mitra PKM berjarak sekitar 53,5 km dari kampus Universitas Muara Bungo dan mudah dijangkau oleh transportasi.

\section{Pelaksanaan Kegiatan}

Metode pelaksanaan pengabdian ini adalah memberikan penyuluhan serta praktik aplikasi teknologi pembuatan silase. Kegiatan penyuluhan berupa memberikan pemahaman kepada kelompok tani tentang budiddaya rumput gajah mini, keunggulan serta urgensi pengawetan hijauan.

Pelaksanaan praktik aplikasi teknologi silase dengan menggunakan mesin pencacah dan bahan-bahan berbasis sumber daya lokal.
Pelaksanaan program PKM pada Wilayah mitra tertera pada Bagan 1.
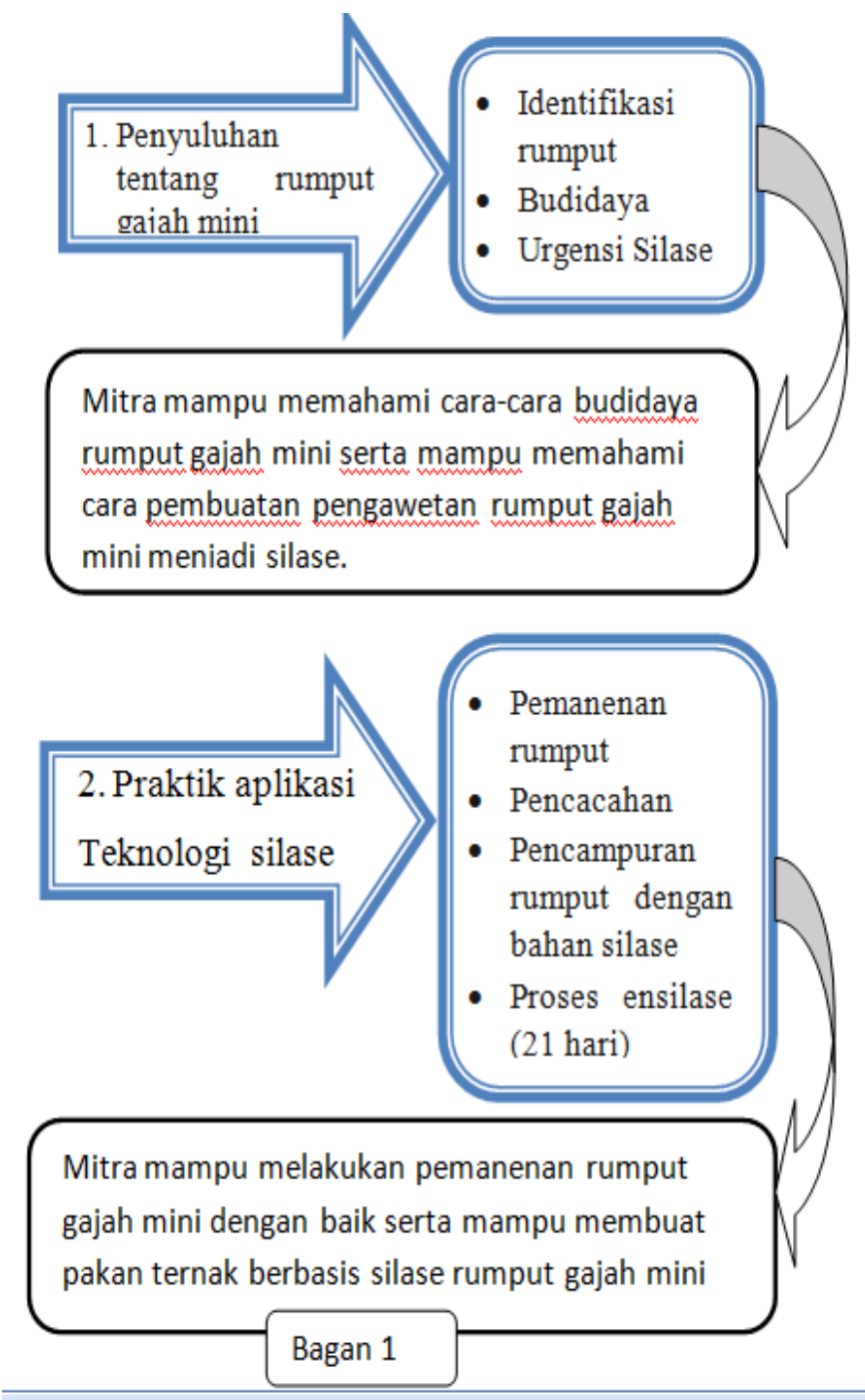

\section{HASIL DAN PEMBAHASAN}

1. Kontribusi Mitra Terhadap Pelaksanaan

Keberhasilan suatu program ditentukan oleh adanya partisipasi dan kontribusi peserta, baik secara langsung maupun tidak. Keberlanjutan program akan dipengaruhi oleh mitra pelaksana. Program dikatakan berhasil apabila dapat diaplikasikan oleh mitra secara terus menerus. Mitra akan terlatih apabila dalam pelaksanaan mitra berperan aktif.

Berbagai kontribusi mitra dalam pelaksanaan pengabdian skema kemitraan masyarakat stimulus dalam rangka menyukseskan

Teknologi Tepat Guna 
program. Berikut kontribusi mitra ditampilkan dalam Tabel 1 dibawah ini;

Tabel 1. Kontribusi Mitra Terhadap Pelaksanaan Program

\begin{tabular}{cl}
\hline No & \multicolumn{1}{c}{ Kontribusi Mitra } \\
\hline 1 & $\begin{array}{l}\text { Keikutsertaan mitra berperan aktif dalam } \\
\text { acara penyuluhan budidaya rumput gajah mini } \\
\text { sehingga mampu mengaplikasikan cara-cara } \\
\text { budidaya rumput gajah mini, serta mampu } \\
\text { melaksanakan pembuatan pengawetan rumput } \\
\text { gajah mini menjadi silase sehingga memiliki } \\
\text { daya simpan yang lama }\end{array}$ \\
2 & $\begin{array}{l}\text { Mitra berpartisipasi aktif dalam mengikuti } \\
\text { budidaya rumput gajah mini serta penerapan } \\
\text { pemumpukan dengan pupuk organik. }\end{array}$ \\
3 & $\begin{array}{l}\text { Mitra berpartisipasi dalam pelaksanaan } \\
\text { praktik budidaya rumput gajah mini, dalam } \\
\text { hal:Penyiapan lokasi, } \\
\text { pemeliharaan, dan pemanenan. }\end{array}$ \\
& $\begin{array}{l}\text { Keterlibatan Mitra dalam Penerapan teknologi } \\
\text { pengolahan Rumput Gajah Mini berbasis } \\
\text { silase. }\end{array}$
\end{tabular}

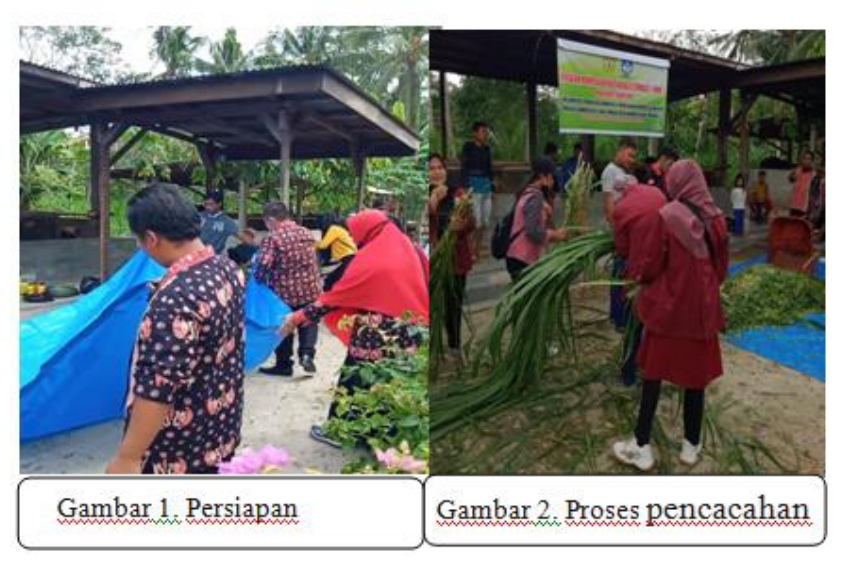

2. Dampak Ekonomi Pasca Kegiatan PKM

Pelaksanaan program kemitraan masyarakat dengan judul implementasi teknologi silase rumput gajah mini menuju desa mandiri pakan ternak memberikan dampak baik secara ekonomis maupun secara sosial bagi kelompok Mitra.

Program kemitraan dengan adanya teknologi silase hijauan pakan ternak memberi dampak perubahan yang sangat tinggi bagi mitra.
Selama ini di saat musim panas dengan kondisi ketersediaan hijauan pakan sangat minim sehingga petani/peternak kesulitan penyediaan pakan. Biasanya dengan kondisi ini biaya input pakan lebih besar karena harus membeli. Akan tetapi dengan adanya teknologi fermentasi silase yang mampu mengawetkan hijauan bertahun-tahun sehingga mitra dan masyarakat sekitar sangat terbantu dengan andanya ketersediaan pakan sepanjang tahun dengan biaya input pakan lebih minim. Lebih jelasnya akan ditampilkan pada Tabel 2 .

Tabel 2. Dampak perubahan Ekonomi setelah kegiatan PKM

\begin{tabular}{|c|c|c|}
\hline $\mathrm{NO}$ & $\begin{array}{l}\text { Kondisi sebelum } \\
\text { Pelaksanaan PKM }\end{array}$ & $\begin{array}{c}\text { Kondisi setelah } \\
\text { Pelaksanaan PKM }\end{array}$ \\
\hline 1 & $\begin{array}{l}\text { Produktivitas hijauan } \\
\text { rendah }\end{array}$ & $\begin{array}{l}\text { Produktivitas hijauan } \\
\text { tinggi }\end{array}$ \\
\hline 2 & $\begin{array}{l}\text { Ketersediaan hijauan } \\
\text { Melimpah di musim } \\
\text { hujan dan minim di } \\
\text { musim kering/panas }\end{array}$ & $\begin{array}{l}\text { Ketersediaan hijauan } \\
\text { melimpah di musim } \\
\text { hujan dan kering }\end{array}$ \\
\hline 3 & $\begin{array}{l}\text { Tidak adanya paket } \\
\text { pakan silase, } \\
\text { sehingga pada } \\
\text { musim kering hanya } \\
\text { mengandalkan pakan } \\
\text { konsentrat komersil }\end{array}$ & $\begin{array}{l}\text { Adanya paket pakan } \\
\text { silase, sehingga pada } \\
\text { pada musim panas } \\
\text { tidak tergantung } \\
\text { dengan pakan } \\
\text { komersil. }\end{array}$ \\
\hline 4 & $\begin{array}{l}\text { Biaya pakan musim } \\
\text { kering/panas sangat } \\
\text { tinggi }\end{array}$ & $\begin{array}{l}\text { Biaya pakan musim } \\
\text { kering/panas rendah }\end{array}$ \\
\hline
\end{tabular}

Tabel 2 menunjukkan bahwa adanya peluang peningkatan pertumbuhan ekonomi setelah pelaksanaan program. Hal ini disebabkan adanya penghematan biaya input awal pada budidaya sapi. Biaya pengeluaran yang terebesar pada usaha budidaya sappi adalah biaya pakan. Sesuai dengan hasil kajian (Rusdiana, dkk 2016) menunjukkan bahwa faktor pakan sangat besar pengaruhnya dalam menentukan keuntungan usaha peternakan.

Adanya penghematan biaya pakan dalam usaha sapi potong pada kelompok mitra setelah penerapan program pengabdian akan berdampak secara ekonomi serta berimplikasi kepada tingkat

$$
\text { Teknologi Tepat Guna }
$$


kesejahteraan masyarakat. Hal ini sejalan dengan hasil penelitian Arwandari dan Indrajaya (2016) menunjukkan bahwa faktor ekonomi sangat signifikan dalam mempengaruhi kesejahteraan masyarakat.

Kendala yang dihadapi oleh Mitra selama ini bisa teratasi dengan adanya penyediaan stok pakan hijauan berbasis silase pada musim panas. Adanya solusi ini dapat meningkatkan semangat kepada mitra untuk terus mengembangkan kebun hijau dan mengaplikasikan pakan silase. Keuntungan pakan berbasis silase selain sebagai pengawetan pakan untuk meningkatkan waktu simpan serta dapat meningkatkan kadar nutrien pakan. Berdasarkan hasil penelitian (Yanuarianto, $d k k$ 2020) menunjukan bahwa ensilase (proses silase) dapat meningkatkan Protein Kasar (PK) pada pakan. Protein Kasar pada pakan sangat signifikan mempengaruhi produktivitas sapi.

Pada kegiatan pengabdian kepada masyarakat ini menggunakan molases sebagai bahan aditif untuk menunjang silase. Dengan adanya penambahan molases pada pakan silase akan meningkatkan palatabilitas dan kandungan gizi padan pakan sehingga dapat meningkatkan tingkat konsumsi dan daya cerna pada ternak. Secara ekonomis, harga molases sangat murah dan mudah untuk didapatkan. Bahan dasar molases adalah tetesan tebu yang banyak ditanam oleh masyarakat. Sesuai dengan pendapat (Yanuarianto, $d k k$ 2020) menyatakan bahwa molases adalah sumber energi yang sering digunakan dengan harga yang relatif lebih urah dibandingkan dengan sumber energi yang lainnya.

Selain penggunaan molases sebagai bahan aditif, pada program pengabdian ini juga menggunakan tanaman Indigofera $s p$. Peran tanaman Indigofera $s p$ pada silase akan meningkatkan kandungan nutrien dan kecernaan. Berdasarkan hasil penelitian (Holik, $d k k$ 2019) menunjukkan bahwa penambahan Indigofera $s p$ pada level (15\%) memberikan kualitas silase yang terbaik serta meningkatkan kecernaan bahan kering (KcBK) dan kecernaan bahan organik (KcBO).

Potensi ketersediaan Indigofera $s p$ pada kelompok mitra tinggi sehingga memudahkan untuk dilaksanakan secara kontinuitas dan berpotensi untuk menunjang kemandirian pakan. Dengan adanya pemanfaatan sumber daya lokal pada program pengabdian ini sangat berpotensi untuk dilaksanakan secara kontinuitas.

Tingginnya kualitas pakan dengan harga yang relatif murah akan menjadi solusi terbaik bagi masyarakat untuk meningkatkan jumlah ternak pada usaha peternakan sapi serta bisa mewujudkan desa madiri pakan ternak.

\section{Dampak perubahan mindset pasca kegiatan PKM}

Setelah pelaksanaan program kegiatan pengabdian masyarakat di Desa Mitra, terjadi perubahan mindset secara signifikant yang ditandai dengan adanya perubahan pola fikir dan semangat untuk menerapkan teknologi silase dalam kehidupan sehari-hari.

Keberhasilan suatu program pengabdian kepada masyarakat ditandai dengan adanya perubahan pola fikir sehingga bisa untuk dilaksanakan secara kontinuitas. Mitra pada program ini sangat muah menerima hal-hal yang baru yang bersifat membangun dan menggerakkan ekonomi masyarakat. Berikut gambaran perubahan mindset diuraikan dalam Tabel 3.

Tabel 3. Dampak perubahan mindset setelah kegiatan PKM

\begin{tabular}{|c|c|c|}
\hline $\mathrm{NO}$ & $\begin{array}{ll}\text { Kondisi } & \text { sebelum } \\
\text { Pelaksanaan } & \text { PKM }\end{array}$ & $\begin{array}{l}\text { Kondisi setelah } \\
\text { Pelaksanaan PKM }\end{array}$ \\
\hline 1 & $\begin{array}{l}\text { Belum mengetahui } \\
\text { identifikasi, budidaya } \\
\text { dan pemanenan } \\
\text { rumput gajah mini. }\end{array}$ & $\begin{array}{l}\text { Sudah mengetahui } \\
\text { identifikasi, budidaya } \\
\text { dan pemanenan } \\
\text { rumput gajah mini } \\
\text { secara baik dan benar. }\end{array}$ \\
\hline 2 & $\begin{array}{l}\text { Belum memahami } \\
\text { konsep dasar } \\
\text { teknologi silase }\end{array}$ & $\begin{array}{l}\text { Sudah memahami } \\
\text { konsep dasar } \\
\text { teknologi silase }\end{array}$ \\
\hline 3 & $\begin{array}{l}\text { Belum mengetahui } \\
\text { cara kerja silase }\end{array}$ & $\begin{array}{l}\text { Sudah mengetahui } \\
\text { cara kerja silase }\end{array}$ \\
\hline 4 & $\begin{array}{l}\text { Belum tertarik } \\
\text { dengan pengawetan } \\
\text { pakan ternak }\end{array}$ & $\begin{array}{l}\text { Sangat tertarik dengan } \\
\text { pengawetan pakan } \\
\text { ternak }\end{array}$ \\
\hline
\end{tabular}


Pada Tabel 3 menunjukan adanya perubahan pola fikir kelompok mitra terhadap program pengabdian masyarakat. Hal ini akan berdampak positif terhadap keberlanjutan program. Masyarakat yang memilki pola fikir yang bisa menerima teknologi baru akan lebih cepat mengalami kemajuan, kemandirian serta meningkatkan kesejahteraan. Pola fikir juga akan menentukan berkualitasnya proses pendidikan. Sejalan dengan (Kodrat, 2019) yang menyatakan bahwa perubahan pola pikir (mindset) menjadi prasyarat mutlak dalam menentukan pendidikan yang berkualitas di tengah masyarakat.

\section{KESIMPULAN}

Berdasarakan kegiatan pengabdian masyarakat yang telah dilaksanakan dapat disimpulkan bahwa terjadinya dampak perubahan pada kelompok Mitra baik secara pola fikir maupun secara ekonomi.

\section{UCAPAN TERIMAKASIH}

Ucapan terimakasih disampaikan kepada;

1) Direktorat Riset dan Pengabdian Masyarakat Diputi Bidang Penguatan Riset dan Pengembangan, Kementerian Riset dan Teknologi / Badan Riset dan Inovasi Nasional yang telah membiayai seluruh kegiatan pengabdian pada masyarakat ini. 2) Prodi Peternakan Fakultas Pertanian Universitas Muara Bungo. Dukungan dan support dari prodi adalah dengan ikut berpartisipasi dalam pelaksanaan program. 3) Sentra Peternakan Rakyat (SPR) wilayah Jambi. Kontribusi dalam pelaksanaan program dengan memberi informasi seputar potensi SPR, ikut berpartisipasi dalam pembuatan pakan silase. 4) Kelompok Purwodadi 2 sebagai mitra dalam menyediakan tempat dan peserta program pengabdian kepada masyarakat.

\section{REFERENSI}

Awandari, L. P. P., \& Indrajaya, I. G. B. (2016). Pengaruh infrastruktur, investasi, dan pertumbuhan ekonomi terhadap kesejahteraan masyarakat melalui kesempatan kerja. E-Jurnal Ekonomi Pembangunan Universitas Udayana, 5(12), 165388.

Astutik, A. S., Mashudi., Irsyammawati, A., \& Ndaru, P. H. (2019). Pengaruh Silase Rumput Odot (Pennisetum purpureum cv. Mott) Dengan Penambahan Bakteri Lactobacillus plantarum Terhadap Produksi Gas dan Kecernaan Secara In Vitro. Jurnal Nutrisi Ternak Tropis, 2 (1) 10-18.

Berampu, I. S., Asril, A., \& Delima, M. (2020). Kualitas Fisik Silase Rumput Gajah Mini (Pennisetum purpureum CV. Mott) Akibat Pemberian Probiotik EM-4 dengan Tambahan Bahan Aditif yang Berbeda. Jurnal Ilmiah Mahasiswa Pertanian, 5(1), 198-202.

Holik, Y. L. A., Abdullah, L., \& Karti, P. (2019). Evaluasi Nutrisi Silase Kultivar Baru Tanaman Sorgum (Sorghum Bicolor) dengan Penambahan Legum Indigofera sp. pada Taraf Berbeda. Jurnal Ilmu Nutrisi dan Teknologi Pakan, 17(2), 38-46.

Kodrat, D. D. (2019). Urgensi Perubahan Pola Pikir Dalam Membangun Pendidikan Bermutu. Jurnal Kajian Peradaban Islam, 2(1), 1-6. https://doi.org/https://doi.org/10.47076/jkpis.v2i1.2 3

Putra, B. (2020). Peranan Pupuk Kotoran Kambing Terhadap Tinggi Tanaman, Jumlah Daun, Lebar dan Luas daun Total Pennisitum purpureum cv. Mott. STOCK Peternakan, 2(2).

Putra, B., putra, mukhlis dwi, \& Pedi Utama, bopalyon. (2020). Pengaruh substitusi sebagian ransum komersil dengan tepung daun indigofera sp terhadap lemak abdomen ayam broiler. Jurnal Sains Peternakan, 8(1),22-29. https://doi.org/10.21067/jsp.v8i01.4515 
Riswandi. (2014). Evaluasi kecernaan silase rumput kumpai (hymenachne acutigluma) dengan penambahan legum turi mini (sesbania rostrata). Jurnal Peternakan Sriwijaya, 3(2), 43-52.

Rusdiana, S., Adiati, U., \& Hutasoit, R. (2016). Analisis ekonomi usaha ternak sapi potong berbasis agroekosistem di Indonesia. Agriekonomika, 5(2), 137-149.

Thalib, I. (2016). Pertumbuhan Rumput Gajah (Pennisetum Purpureum Cv. Mott) Pada Berbagai Konsentrasi Media Murashige dan Skoog Dengan Teknik Kultur Jaringan. Makasar: Fakultas Peternakan Universitas Hasanuddin.

Yanuarianto, O., Amin, M., Hasan, S. D., Dilaga, S. H., \& Suhubdy, S. (2020). Komposisi Nutrisi dan Kecernaan Silase Jerami Jagung yang Ditambah Lamtoro dan Molases yang Difermentasi pada Waktu Berbeda. Jurnal Ilmu dan Teknologi Peternakan Indonesia (JITPI), Indonesian Journal of Animal Science and Technology, 6(1), 16-23.

Yitbarek, M. B. and B. Tamir, 2014. Silage Additives: Review. Open Journal of Applied Sciences 4: 258-278. 